\title{
Pre-Columbian Dental Modifications in Costa Rica: A Study of Three Archaeological Sites
}

\section{Modificaciones dentales precolombinas en Costa Rica: Estudio de tres sitios arqueológicos}

\author{
Irene Valerio-Alfaro MScㄹ; Daniel Chavarría-Bolaños MSc, PhD²
}

1. Restorative Sciences Department, Faculty of Dentistry, Universidad de Costa Rica, Costa Rica.

2. Diagnostic and Surgical Sciences Department, Faculty of Dentistry, Universidad de Costa Rica, Costa Rica.

Correspondence to: Dr. Daniel Chavarría Bolaños - daniel.chavarria@ucr.ac.cr / danielchava2@gmail.com

Received: 1-|I-2017

Accepted: 21-II-2017

Published Online First: 24-II-2017

D0l: http://dx.doi.org/10.15517/ijds.v0i0.28054

\section{ABSTRACT}

The aim of the study was to evaluate the presence and characteristics of dental modifications in pre-Columbian populations from three archaeological sites in the Costa Rican territory (Nacascolo, Jícaro and La Cascabel) in order to describe them according to previous classification. Specimens were obtained from the collections of the National Museum of Costa Rica. All specimens were macroscopically analyzed and the pieces were classified. Photographic records were taken to each piece and a full description was done. Sixty one pieces with dental modifications were found. The types of dental modifications found were classified as A1, C2/C6, A2, C2, C1, E1 and A3 in order of prevalence. In conclusion, dental modifications were found in most of specimens. Particularly, C2/C6 modification was not reported by previous classifications.

\section{KEYWORDS}

Dental modification; Pre-Columbian; Costa Rica. 


\section{RESUMEN}

El objetivo del estudio fue evaluar la presencia y características de las modificaciones dentales de las poblaciones precolombinas de tres sitios arqueológicos en el territorio Costarricense (Nacascolo, Jícaro y La Cascabel) con el fin de describirlas de acuerdo a una clasificación previa. Los especímenes fueron obtenidos de las colecciones del Museo Nacional de Costa Rica. Todos los especímenes fueron analizados macroscópicamente y las piezas fueron clasificadas. Cada pieza contó con un registro fotográfico y una descripción completa. Sesenta y un piezas fueron encontradas con modificaciones dentales. Los tipos de modificaciones dentales encontrados fueron clasificados como A1, C2/C6, A2, C2, C1 E1 y A3 en orden de prevalencia. En conclusión, en la mayoría de piezas dentales analizadas se encontraron modificaciones dentales. Particularmente, la modificación C2/C6 no ha sido reportada por clasificaciones previas.

\section{PALABRAS CLAVE}

Modificaciones dentales; Precolombino; Costa Rica.

\section{INTRODUCTION}

Body modifications for cultural purposes, such as the intentional deformation of the head and the alterations of dental appearance (fillings or inlays between incisor teeth), have been documented in different geographical areas (1-5). Other expressions like tattoos and lobe perforations or depilation have survived even in the most civilized societies (6).

Biomedical and anthropological studies of the aboriginal populations have increased in order to obtain a greater comprehension of the cultural, genetic and ecological structure of these groups. (3, 7-10). The cultural significance of dental mutilations includes tradition, ritualism and routine ornamental pieces that represent cultural identity $(4,5,11)$. As an example, the extraction of a canine or an incisive may indicate the nobility of the woman or maturity of the man; it may be the result of a duel or punishment; or it may have been carried out for aesthetic enhancement or caries' prevention $(2,12)$.

The term dental modification refers to specific non-reversible treatments that permanently alter the tooth surface morphology. Such practices include a wide range of techniques, from surface smoothing to aggressive inlay preparations (1, 4, 5). Historically, three areas can be distinguished by the presence of dental modifications: Africa, Central/South America and the Philippines/Malay Archipelago, especially during the 1400 BC - 1400 AD period (13).

An inlay represents an advanced technique of dental work. It is estimated that $20-60 \%$ of Mayan pre-Columbian adults were subjected to dental modifications. Tiesler (2) and Williams (5) proposed that the acceptance of the intervention (besides its possible health risks) may represent a high social status. The practice of modified teeth was considered a special ritual of itself and recognized members of the society were in charge of it (14) or as Pompa y Padilla suggested it was made by women (4).

Nowadays, investigation of pre-Columbian dental modifications follow the typology of Romero (15) which identify seven basic types. Other less used classifications were the ones reported by Saville in 1913 or De Borbolla in 1944 (6). 
The first dental modifications in Costa Rica were found in the Moral de San Blas region, described by Stone in 1977, and the second were found in the Atlantic Slop. In Colorado of Abangares, there are reports of smoothed incisive discovered in Bagaces's cemetery (16). In the Guinea region in 1979, John Hoopes reported two incisors with dental modifications near to fine ceramic works (17). In The Conchal site, a multiple burial had a principal individual who presented smoothed upper incisors. (16). More recently in 1983 this practice was reported as non-frequent but still practiced mainly for esthetic purposes within specific populations (8). Thus, the aim of this investigation was to describe the den-tal modifications found in three different Costa Rican archeological sites.

\section{MATERIALS AND METHODS}

This observational descriptive study analyzed selected dental specimens recovered from 3 different archeological sites near Bahia Culebra, located in the pacific area of Costa Rica (specifically the sites of Jícaro, Nacascolo and La Cascabel, located in the archaeological region of Gran Nicoya). All pieces belong to the collections of the Department of Protection of Cultural Patrimony and the Department of Anthropology and History of the Costa Rica National Museum and were analyzed under the authorization codes DGM-249-2009 and DAH-159-2009.

Each sample was examined and selected according to previously established crite-ria. Inclusion criteria were as follows: complete or partial crania (maxillas or individual jaws) with dental modifications. Exclusion criteria were as follows: crania (jaws or maxillas) that only presented posterior dental pieces, previous free pieces without modifications or with extensive frontal loss or where severe attrition was suspected, dental pieces with advanced caries' conditions or other dental pathologies.

All selected dental specimens showing modifications were photographically recorded and compared with a schematic drawing including a brief description when it was needed. Data was analyzed and a descriptive statistical analysis was done.

\section{RESULTS}

Sixty one dental pieces were identified (Table 1). Within these dental modifications, type $A 1$ and $A 2$ were the most common within all collected samples. Figure 1 shows the distribution of each modification according to geographical origin. Type A1 has a notch of changeable depth in the center of the incisal edge and type A2 has two indentations in the incisal edge (Figure 2). Fourteen lower anterior teeth presented dental modifications not clearly typified in J. Romero's classification.

Table 1. Classification of the total sample of dental modifications.

\begin{tabular}{cc}
\hline Type & Percentaje (\%) \\
\hline A1 & 43.14 \\
A2 & 15.69 \\
A3 & 1.96 \\
C1 & 5.89 \\
C2 & 13.73 \\
C2/C6 & 17.65 \\
E1 & 1.96 \\
\hline
\end{tabular}




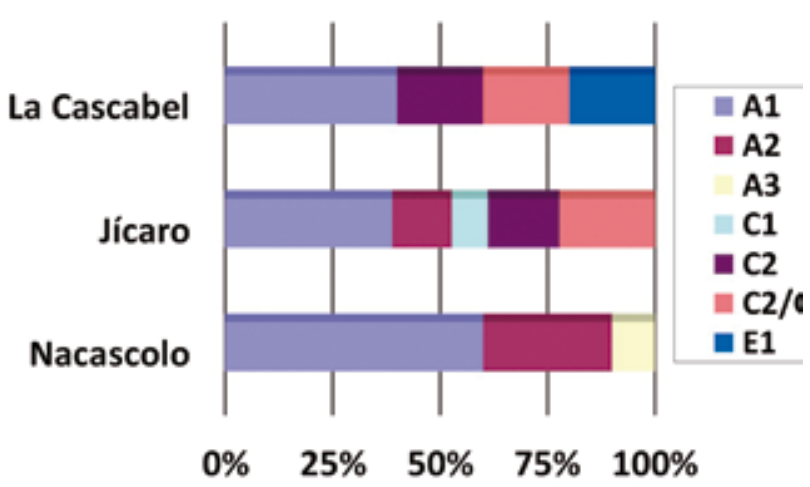

Figure 1. Distribution of dental modifications according to the archeological site.

\section{A}
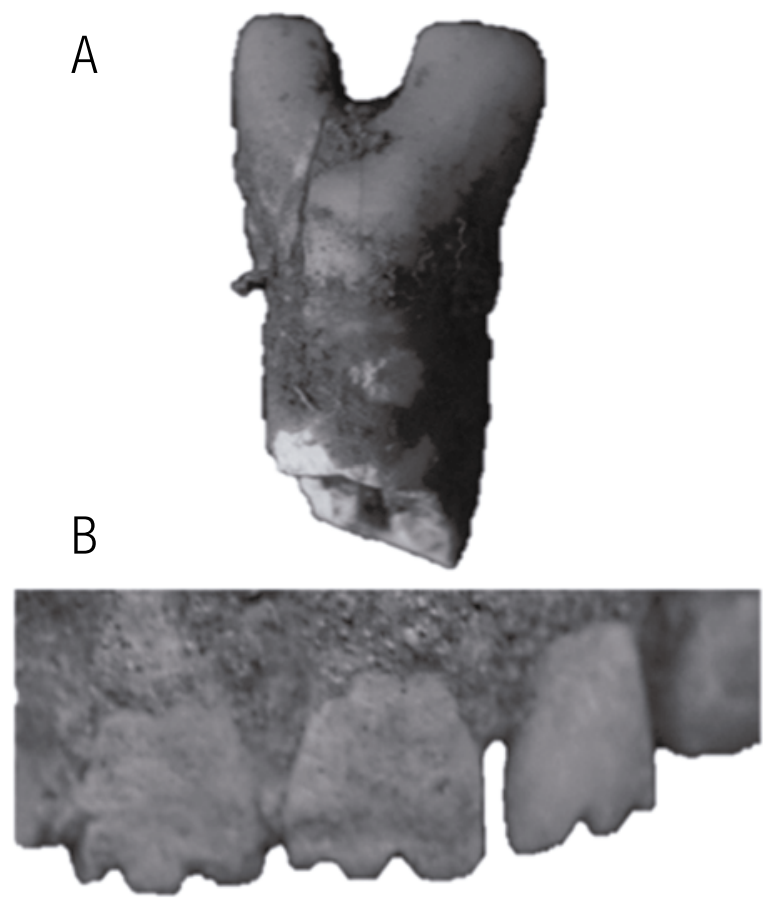

Figure 2. Nacascolo archeological site representative specimens. A. A1 type, B. A2 type).

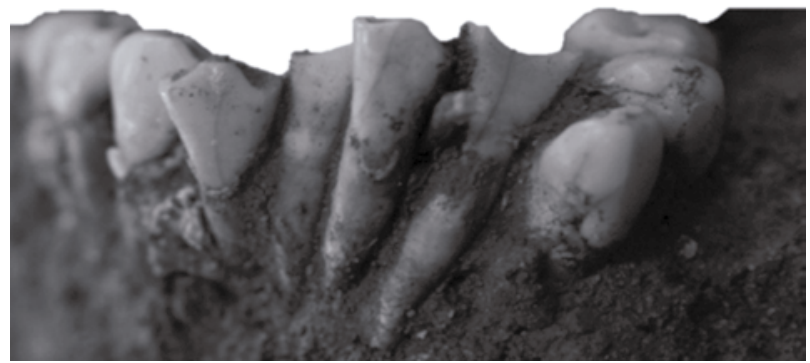

Figure 3. Jícaro archeological site non-classifiable specimen C2/C6.
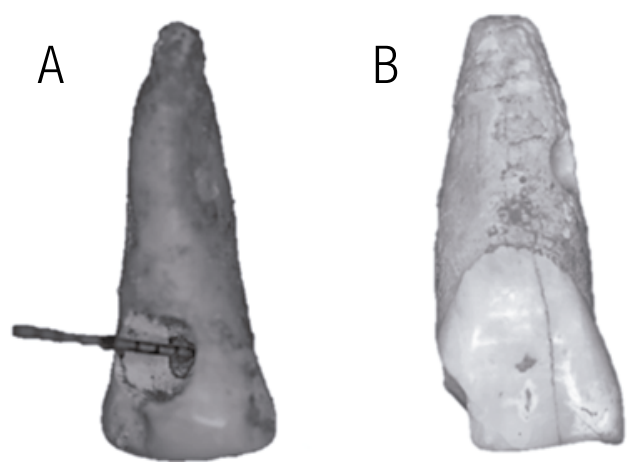

Figure 4. La Cascabel specimens (A. type $\mathrm{E} 1$ without inlay $3 \mathrm{~mm}$ depth measurement, B. questionable unclassified sample).

\section{DISCUSSION}

The Guanacaste archaeological regions of Costa Rica are well known, thanks to uninterrupted projects executed by regional researches throughout several decades. This is the particular case of Bahía Culebra's zone and specifically of Nacascolo's Peninsula, where in the last 30 years investigations have identified new archaeological sites and 
detailed the activities and cultivable processes of the area. Bahía Culebra is crucial to calculating the cultural development of Costa Rica's coastal pre-Columbian populations (16).

Five decades of subsequent excavation and analysis have uncovered several dental modifications that do not fit neatly into these categories (12). Dental modifications found in 14 anterior lower teeth have been catalogued in this study as type C2/ C6 due to the presence of double modified incisal angles (Figure 3). This type of dental modification is distinguished because of the presence of the incisal edge of the group $C$ (that includes both angles) but with a different height, where one of the planes is longer than the other, where the apex is not centered and the distance towards the same one is curvilinear. To be classified as Romero's "F" category, both angles must be included, and in the vestibular face modifications must be present. The type C2/C6 described here lacks this morphological characteristic.

Only type E1 was found in La Cascabel's site with a depth of $3 \mathrm{~mm}$ without the inlay gem (Figure 4.a). In other study type E1 only occurred on elite males' dentition (12). This piece was found to be out of context and not corresponding to or associated with any individual. In Jícaro and La Cascabel's sites, four accounts of hand bracelets with 10-19 dental pieces were found, but just three of them showed dental modifications corresponding to $A 1$, C2 and C2/C6.

Regarding the dental modifications found, besides the teeth with clear dental works, there were ten suspicious findings but they were excluded due to different reasons such as mechanical or chemical dental wear (18-19) fractures, time damage and sand or mineral deposits around them (Figure 4.b).
It is important to emphasize that within the three studied sites, Jícaro represents the best temporary location, thanks to numerous Carbon 14 tests that date it between 1000 and $1300 \mathrm{aC}$.

Many individuals present cranial deformation and dental filings, where the cranial deformation was the more frequent within both sexes, whereas teeth smoothing only happen in masculine individuals (20). However, in this study most of the cases lacks of information about the gender or age of the individuals; thus this correlation was not possible to establish $(9,21)$.

The physical characteristics of some buried individuals suggest a possible immigration process of people of Indo-American origin who established themselves in the zone (10). They developed knowledge and skills for work on shells from which they did tools and adornments. Cranial deformation and dental filings, with the exception of two cases in Nacascolo $(17,22)$, suggest that Jícaro was the first of the sites where it was possible to document the arrival and permanency of an immigrant group (20).

As previous studies on dental modifications show $(2,5-6,11)$, the anterior teeth were clearly the target to be modified, beginning by the central incisor and followed by the lateral incisor and the canine, respectively. These distributions appear similar in the maxillary and mandibular dentition.

Throughouthistory, the human beings left traces of their evolution, including important expressions currently seen as artistic like graphic expressions or sculpture (23-25). In this study, it was not possible to establish a relationship between the design of preColumbian ceramics and the archaeological findings of human remains, especially on dental fillings and mutilations different from other archeological sites 
like Mexico (26). In Costa Rica, just a few ceramic jars had been found with clear dental modifications repre-senting type A1 (27). Further efforts must be developed to increase the knowledge of pre-Columbian dental work, employing current technological advances $(9,19,28)$.

\section{CONCLUSIONS}

This research concludes that dental modifications were a common practice within aboriginal Costa Rican groups in the Guanacaste region. The types of dental modifications found were $A 1, C 2 / C 6, A 2, C 2, C 1, E 1$ and $A 3$, in order of prevalence. Type $\mathrm{C} 2 / \mathrm{C} 6$ was not reported by previous classifications.

\section{CONFLICT OF INTEREST}

The authors declare that they have no competing interests.

\section{ACKNOWLEDGMENTS}

The authors thank Dr. William Brenes for his guidance during the data recollection of this project. The authors thank Dr. Mauricio Montero Aguilar from the Universidad de Costa Rica and Dr Bernardino Isaac Cerda Cristerna from the Universidad Veracruzana, México; for the critical review of the current article. We also thanks the Publications and Scientific Production Program of the University of Costa Rica, and the authorities of the National Museum of Costa Rica for its technical support. We thank City Hills Proof for their assistance in editing this manuscript.

\section{REFERENCES}

1. Handler J. S., Corruccini R.S., Mutaw R. J. 1982. Tooth Mutilation in the Caribbean: Ev-idence from a Slave Burial Population in Barbados. J Hum Evol 11, 297-313.
2. Tiesler V. 2001. Decoraciones dentales entre los antiguos mayas. D.F, Mexico: Instituto Nacional de Antropología e Historia. Eds. Euroafricanas.

3. Bernal V., Luna L. H. 2011. The development of dental research in Argentinean biological anthropology: Current state and future. HOMO 62: 315-32.

4. Pompa y Padilla JA. 1995. El embellecimiento dentario en la época prehispánica. Ar-queología Mexicana 3: 92-63.

5. Williams J. S., White C. D. 2006. Dental modification in the postclassic population from Lamanai, Belize. Anc Mesoam 17: 139-151.

6. Labajo González E., Parea Pérez B., Sánchez Sánchez J. A., Robledo Acinas M Mar. 2008. Dental aesthetics as an expression of culture and ritual. Br Dent J 208: 77-80.

7. Tesi G. 1982. Racial Groups in the Region around Chott E1 Djerid, Southern Tunisia. J Hum Evol 11, 265-287.

8. Brenes W., Barrantes R. 1983. Salud Oral y Morfología dental de los Amerindios Guaymí de Limoncito. Am Indig 43: 215-227.

9. Luna L. H., Bernal V. 2011. Current status and perspectives of the development of dental research in biological anthropology of Argentina: Introduction and conclusions of the symposium. HOMO 62: 328-334.

10. Kondo S., Manabe Y. 2016. Review Analytical methods and interpretation of variation in tooth morphology. J Oral Biosci 58: 85-94.

11. Valerio I. 2012. Estética Dental Precolombina basada en el estudio de los Patrones Visuales. Rev Cient. Odontol (8) 2: 26-29.

12. GellerP.Altering Identities: Body Modifications and the Pre-Columbian Maya. The Social Archaeology of Funerary Remains, Publisher: Oxbow Books, Editors: Rebecca Gowland, Christopher Knüsel, pp.279-91.

13. Arcini, C. 2005. The Vikins Bare Their Fiel Teeth. Am. J Phys Anthropol 128: 727-733.

14. Salas M.A., Rivas J. 2001. La odontología del pueblo maya. Rev Asoc Dent Mex 58: 105-107. 
15. Romero J. 1986. Catálogo de la colección de dientes mutilados prehispánicos IV parte. D.F, Mexico: Instituto Nacional de Antropología e Historia.

16. Solis F., Herrera A. 2006. Informe final de Investigación, I Temporada. Jícaro: una comunidad de pescadores y artesanos. (Report to the Comisión Arqueológica Nacional) San José, Costa Rica.

17. Wallace H., Accola R. 1980. Investigaciones arqueológicas preliminares de Nacascolo, Bahía Culebra, Costa Rica. Vínculos 6: 51-65.

18. Tomczyk J., Zalewska M. 2016. Mechanical and chemical dental wear in historical population from the Syrian lower Euphrates valley. Arch Oral Biol 62: 49-57.

19. Pinilla B., Trinkaus E. 2014. Buccal dental microwear and diet of the Sunghir upper paleolithic modern humans. Archaeology, Ethnology and Anthropology of Eurasia 42: 131-142.

20. Solis F., Herrera A. 2007. Avance de Investigación II Temporada de labores en el sitio Arqueológico Jícaro (G-439Ji). (Report to the Comisión Arqueológica Nacional) San José, Costa Rica.

21. Bocquet-Appel J.P., Masset C. 1982. Farewell to Paleodernography. J Hum Evol 11, 321-333.

22. Obando P. 1995. Childhood stress and bone maintenance in prehistoric north and west- ern Costa Rica: an analysis of two coastal populations, Nacascolo and Vidor. (Master's thesis) University of Colorado, CO.

23. Sharapov V. E., Zemtsova I.V. 2014. Wood painting tradition of the upper Vychegda Komi in the last 19 the first quarter of the 20th century. Archaeology, Ethnology and Anthropology of Eurasia 42: 119-122.

24. Kovtun I.V., Marochkin A.G. 2014. The Olgaya-1 site and the Novoromanovo rock art gallery: A tentative interpretation with regard to mythology and seasonal rites. Archaeology, Ethnology and Anthropology of Eurasia 42: 101-110.

25. Koksharov S.F. 2014. Bronze age animal figurines from the Taiga zone of the OB re-gion. Archaeology, Ethnology and Anthropology of Eurasia 42: 77-81.

26. Beltrán del Río, GRA. 2007. Apreciación estética odontológica de la cerámica prehispánica. Rev Asoc Dent Mex 64: 221-225.

27. Soto Z. 2002. Arte Precolombino Costarricense del Museo del Jade Marco Fidel Tris-tán. San José, Costa Rica: Instituto Nacional de Seguros.

28. Zimmerman H. A., Meizel-Lambert C. J., Schultz J. J., Sigman M.E. 2015. Chemical Dif-ferentiation of Osseous, Dental, and Nonskeletal Materials in Forensic Anthropology using Elemental Analysis. Science and Justice 55: 131-138. 